Pacific Journal of Mathematics

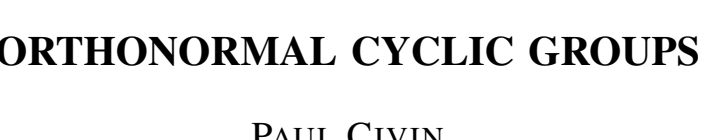




\title{
ORTHONORMAL CYCLIC GROUPS
}

\author{
Paul Civin
}

In an earlier paper [1] a characterization was given of the Walsh functions in terms of their group structure and orthogonality. The object of the present note is to present a similar result concerning the complex exponentials.

THEOREM. Let $\left\{A_{n}(x)\right\}(n=0, \pm 1, \ldots ; 0 \leq x \leq 1)$ be a set of complexvalued measurable functions which is a multiplicative cyclic group. A necessary and sufficient condition that $\left\{A_{n}(x)\right\}$ be an orthonormal system over $0 \leq x \leq 1$ is that the generator of the group admit a representation $\exp (2 \pi i c(x))$ almost everywhere, with $c(x)$ equimeasurable with $x$.

As the sufficiency is immediate, we present only the proof of the necessity. Let the notation be chosen so that the generator of the group is $A_{1}(x)$, and

$$
A_{n}(x)=\left(A_{1}(x)\right)^{n} \quad(n=0, \pm 1, \ldots) .
$$

The normality implies $\left|A_{1}(x)\right|=1$ almost everywhere. Hence there is a measurable $a(x), 0 \leq a(x)<1$, such that

$$
A_{1}(x)=\exp (2 \pi i a(x))
$$

almost everywhere. Let $b(x)$ be a function [2, p. 207] monotonically increasing and equimeasurable with $a(x)$. Also let

$$
c(x)=m\{u: 0 \leq u \leq 1, b(u) \leq x\} \quad(-\infty<x<\infty) .
$$

The orthonormal condition becomes

$$
\delta_{0, n}=\int_{0}^{1} \exp (2 \pi n i b(x)) d x=\int_{-\infty}^{\infty} \exp (2 \pi n i y) d c(y),
$$

where the latter integral is a Lebesgue-Stieltjes integral. Thus for any $\epsilon>0$,

Received February 6, 1953.

Pacific J. Math. 4 (1954), 481- 482 


$$
\begin{aligned}
\delta_{0, n}=\int_{b(0)-\epsilon}^{b(1)} \exp (2 \pi n i y) d c(v) \\
\quad=\int_{b(0)}^{b(1)} \exp (2 \pi n i y) d c(y)+\exp (2 \pi n i b(0)) \quad m\{x: b(x)=b(0)\},
\end{aligned}
$$

and the latter integral is interpretable as a Riemann-Stieltjes integral.

Integration by parts yields

$$
\delta_{0, n}=\exp (2 \pi n i b(1))-2 \pi n i \int_{b(0)}^{b(1)} c(y) \exp (2 \pi n i y) d y
$$

If $f(y)=y, 0<y \leq 1$, and $f(y+1)=f(y)$, a direct calculation shows that

$$
\delta_{0, n}=\exp (2 \pi n i b(1))-2 \pi n i \int_{0}^{1} f(y-b(1)) \exp (2 \pi n i y) d y
$$

Formulas (1) and (2), and the completeness of the complex exponentials, imply the existence of a constant $k$ such that for almost all $y, 0<y \leq 1$,

$$
f(y-b(1))+k= \begin{cases}0, & 0<y \leq b(0) \\ c(y), & b(0)<y \leq b(1) \\ 0, & b(1)<y \leq 1 .\end{cases}
$$

Since the supremum of $c(y)$ is one, and $f(y)$ has no interval of constancy, one infers that $k=0, b(0)=0$, and $b(1)=1$. Thus $c(y)=y, 0<y \leq 1$, which is equivalent to the proposition that was asserted.

\section{REFERENCES}

1. P. Civin, Multiplicative closure and the Walsh functions, Pacific J. Math. 2 (1952), 291 - 296.

2. N. J. Fine, On groups of orthonormal functions, Pacific J. Math. (to appear).

3. - On groups of orthonormal functions, II, Pacific J. Math. (to appear).

4. D. Jackson, Proof of a theorem of Haskins, Transa. Amer. Math. Soc. 17 (1916), $178-180$.

5. A. Zygmund, Trigonometrical series, Warsaw-Lvov, 1935. 


\section{PACIFIC JOURNAL OF MATHEMATICS}

\section{EDITORS}

\author{
M.M. SCHIFFER * \\ Stanford University \\ Stanford, California \\ E. HEWITT \\ University of Washington \\ Seattle 5, Washington
}

\section{R.P. DILWORTH}

California Institute of Technology Pasadena 4, California

\section{E. F. BECKENBACH**}

University of California

Los Angeles 24, California

\section{ASSOCIATE EDITORS}

$\begin{array}{llll}\text { H. BUSEMANN } & \text { P.R. HALMOS } & \text { BØRGE JESSEN } & \text { J. J. STOKER } \\ \text { HERBERT FEDERER } & \text { HEINZ HOPF } & \text { PAUL LÉVY } & \text { E.G. STRAUS } \\ \text { MARSHALL HALL } & \text { R.D. JAMES } & \text { GEORGE PÓLYA } & \text { KÔSAKU YOSIDA }\end{array}$

\section{SPONSORS}

UNIVERSITY OF BRITISH COLUMBIA

CALIFORNIA INSTITUTE OF TECHNOLOGY

UNIVERSITY OF CALIFORNIA, BERKELEY

UNIVERSITY OF CALIFORNIA, DAVIS

UNIVERSITY OF CALIFORNIA, LOS ANGELES

UNIVERSITY OF CALIFORNIA, SANTA BARBARA

UNIVERSITY OF NEVADA

OREGON STATE COLLEGE

UNIVERSITY OF OREGON
UNIVERSITY OF SOUTHERN CALIFORNIA STANFORD RESEARCH INSTITUTE STANFORD UNIVERSITY WASHINGTON STATE COLLEGE UNIVERSITY OF WASHINGTON

AMERICAN MATHEMATICAL SOCIETY HUGHES AIRCRAFT COMPANY

Mathematical papers intended for publication in the Pacific Journal of Mathematics should be typewritten (double spaced), and the author should keep a complete copy. Manuscripts may be sent to any of the editors. Manuscripts intended for the outgoing editors should be sent to their successors. All other communications to the editors should be addressed to the managing editor, E.G. Straus, at the University of California Los Angeles 24, California.

50 reprints of each article are furnished free of charge; additional copies may be obtained at cost in multiples of 50 .

The Pacific Journal of Mathematics is published quarterly, in March, June, September, and December. The price per volume (4 numbers) is $\$ 12.00$; single issues, $\$ 3.50$; back numbers (Volumes $1,2,3$ ) are available at $\$ 2.50$ per copy. Special price to individual faculty members of supporting institutions and to individual members of the American Mathematical Society: $\$ 4.00$ per volume; single issues, $\$ 1.25$.

Subscriptions, orders for back numbers, and changes of address should be sent to the publishers, University of California Press, ,Berkeley 4, California.

Printed at Ann Arbor, Michigan. Entered as second class matter at the Post Office, Berkeley, California.

* To be succeeded in 1955, by H.L. Royden, Stanford University, Stanford, California.

** To be succeeded in 1955, by E.G. Straus, University of California, Los Angeles 24, Calif.

UNIVERSITY OF CALIFORNIA PRESS - BERKELEY AND LOS ANGELES 


\section{Pacific Journal of Mathematics}

\section{Vol. 4, No. $4 \quad$ August, 1954}

Paul Civin, Orthonormal cyclic groups .................... 481

Kenneth Lloyd Cooke, The rate of increase of real continuous solutions of

algebraic differential-difference equations of the first order ......... 483

Philip J. Davis, Linear functional equations and interpolation series . . . . . 503

F. Herzog and G. Piranian, Sets of radial continuity of analytic functions . . 533

P. C. Rosenbloom, Comments on the preceding paper by Herzog and

Piranian ............................................. 539

Donald G. Higman, Remarks on splitting extensions .............. 545

Margaret Jackson, Transformations of series of the type ${ }_{3} \Psi_{3} \ldots \ldots \ldots \ldots 557$

Herman Rubin and Patrick Colonel Suppes, Transformations of systems of relativistic particle mechanics ....................... 563

A. Seidenberg, On the dimension theory of rings. II .............. 603

Bertram Yood, Difference algebras of linear transformations on a Banach

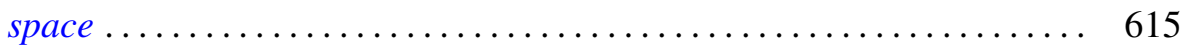

